\title{
Atraumatic care dengan spalk manakara pada pemasangan infus efektif menurunkan tingkat kecemasan anak pra sekolah
}

\author{
Zulhaini Sartika A. Pulungan ${ }^{1 *}$, Yusuf ${ }^{2}$, Ni Komang Sudiartini ${ }^{3}$, Muh. Zen ${ }^{4}$, Muhammad Irfan Ali $^{5}$, Widyatma Arya \\ Sawitra ${ }^{6}$, Edi Purnomo \\ Jurusan Keperawatan Politeknik Kesehatan Kementerian Kesehatan Mamuju
}

Keywords :

atraumatic care, infusion installation, Spalk Manakarra

\section{Kontak :}

Zulhaini Sartika A. Pulungan Email : zulhainisartika@gmail.com Jurusan Keperawatan Politeknik Kesehatan Kementerian Kesehatan Mamuju

Vol 2 No 1 September 2019

DOI: https://doi.org/10.31605/jhealt.v2i1

(C)2018J-Healt

ini adalah artikel dengan akses terbuka dibawah licenci CC BY-NC-4.0

https://creativecommons.org/licenses/by-nc/4.0/
Abstract

Children are vulnerable to disease crises and hospitalization, due to stress, changes in health and environmental routine in hospitals. Atraumatic care is therapeutic care through interventions that serve to reduce the psychological and physical distress suffered by the child and his family in the health care system. One way atraumatic care in children during infusion is by installing spalk. Spalk Manakarra is modified to reduce child's anxiety level on infusion as one of the efforts in performing atraumatic care. This study aims to determine the effectiveness of atraumatic care with "Spalk Manakarra" on the installation of infusion of anxiety levels of pre school children in RSUD Kab. Mamuju. The benefits of this study are expected to be useful input as a spalk alternative that can reduce the anxiety of children on the installation of infus in the hospital. This research is a quasi experimental research with pretest and posttest design with control group design. The study population were all children treated in child care room of RSUD Kab. Mamuju. Sampling using purposive sampling technique. The sample size is 30 people. Data analysis was done by using independent sample t test to know the average of control group anxiety level and intervention group using Spalk Manakarra. The results showed that there was a significant difference in pre school level of anxiety of pre-school students who installed spalk manakarra compared with that of spalk hospital with $p=0,026$. Conclusion: The use of Spalk Manakarra is more effective in reducing pre school children's anxiety levels in intravenous infusions. 


\section{PENDAHULUAN}

Anak adalah mahluk unik yang memiliki kebutuhan berbeda disetiap tahap tumbuh kembangnya, oleh karena itu orang tua perlu memahami pentingnya menyediakan fasilitas untuk mendukung pertumbuhan dan perkembangan tersebut (Cahyaningrum, 2012). Anak usia pra sekolah adalah usia perkembangan yang dimulai pada usia 3 sampai 6 tahun (Muscari, 2005). Pada masa ini anak memandang bahwa penyakit sebagai suatu hukuman, sehingga ketika anak sakit dan mengalami hospitalisasi dapat menimbulkan stres pada anak. Stressor yang ditunjukkan dapat berupa cemas, kehilangan kendali, cedera tubuh, dan nyeri. Stres hospitalisasi dapat memberikan efek pada perilaku anak saat pemulangan seperti menuntut perhatian lebih dari orang tua, sangat menentang perpisahan, ketakutan baru, terbangun di malam hari, menarik diri, pemalu, rewel, dan tempertantrum (Wong et al., 2009).

Survey awal yang dilakukan di RSUD Kabupaten Mamuju, jumlah anak yang dirawat di ruang perawatan anak semakin meningkat. Kondisi anak yang dirawat sering gelisah, rewel dan selalu ingin ditemani saat menjalani proses perawatan. Anak juga sering menangis dan mengatakan ingin pulang. Penyebab kecemasan yang dialami beragam, mulai dari rasa cemas terhadap petugas kesehatan, tindakan medis, nyeri yang dialami, cemas karena berada pada tempat dan lingkungan baru, cemas akibat perpisahan dengan teman dan saudaranya. Hal ini sejalan dengan data The National Centre for Health Statistic yang memperkirakan bahwa 3-5 juta anak di bawah usia 15 tahun menjalani hospitalisasi setiap tahun. Angka kesakitan anak di Indonesia yang dirawat di rumah sakit juga cukup tinggi yaitu $15,26 \%$ yang ditunjukkan dengan selalu penuhnya ruangan anak baik rumah sakit pemerintah maupun swasta. Bila dibandingkan angka kesakitan anak di daerah perdesaan dan perkotaan menunjukkan angka kesakitan di pedesaan lebih tinggi dibanding perkotaan $(15,75$ vs $14,74 \%)$. Berdasarkan survei kesehatan ibu dan anak tahun 2010 juga didapatkan hasil bahwa dari 1.425 anak yang mengalami dampak hospitalisasi, 33,2\% diantaranya mengalami dampak hospitalisasi berat, 41,6\% mengalami dampak hospitalisasi sedang, dan $25,2 \%$ mengalami dampak hospitalisasi ringan (Kementerian Pemberdayaan Perempuan dan Perlindungan Anak, 2015).

Selama hospitalisasi pada umumnya asuhan keperawatan pada anak memerlukan tindakan invasif berupa injeksi maupun pemasangan infus. Injeksi merupakan tindakan medis yang sering ditakuti oleh anak dan bisa terbawa sampai dewasa. Respon anak tersebut dapat menjadi kendala dalam pelaksanaan asuhan keperawatan yang akan diberikan sehingga menghambat proses penyembuhan dan mengakibatkan perawatan yang lebih lama bahkan akan mempercepat terjadinya komplikasi-komplikasi selama perawatan (Nursalam, Susilaningrum, \& Utami, 2005). Terpaparnya anak pada kejadian traumatik pada masa kecil akan memberikan pengalaman yang tidak menyenangkan dalam waktu yang lama, tidak hanya pada anak tetapi lingkungan terutama keluarga juga akan terpengaruh (Fletcher, 2003).

Intervensi keperawatan dalam upaya mengatasi masalah yang timbul pada anak maupun orang tua selama hospitalisasi adalah meminimalkan stressor, memaksimalkan manfaat hospitalisasi, memberikan dukungan psikologi terhadap anggota keluarga dan mempersiapkan anak sebelum hospialisasi (Supartini, 2004). Atraumatic care merupakan suatu tindakan asuhan keperawatan yang terapeutik dengan menyediakan lingkungan yang nyaman oleh petugas kesehatan, dan menggunakan intervensi yang menghilangkan atau mengurangi distress fisik maupun psikologis pada anak-anak dan keluarga dalam sistem pelayanan kesehatan. Prinsip yang mendasari atraumatic care adalah bagaimana mencegah atau mengurangi pemisahan anak dan keluarga; meningkatkan pengendalian diri pada anak; dan mencegah atau mengurangi nyeri dan cedera pada tubuh (Wong et al., 2009). Beberapa contoh tindakan atraumatic care adalah dengan memodifikasi lingkungan rumah sakit seperti di rumah sendiri. Dekorasi bernuansa anak seperti tirai, hiasan dinding 
dan papan nama bergambar binatang lucu, sprei bergambar bunga, dan dinding dicat dengan warna cerah (Supartini, 2004).

Hasil penelitian yang mengeksplorasi tentang atraumatic care seperti penelitian yang dilakukan oleh Festini et al. (2009) dengan menggunakan pakaian perawat non konvensional atau seragam perawat berwarna menunjukkan peningkatan hubungan antara anak dan perawat dan berpotensi mengurangi ketidaknyamanan yang dialami anak karena hospitalisasi. Hal ini dapat diterapkan pada penelitian serupa dengan pemasangan Spalk Manakarra pada anak untuk menurunkan tingkat kecemasan selama pemasangan infus. Penggunaan spalk atau bidai pada anak pada pemasangan infus dapat mengurangi resiko komplikasi (Batalha et al., 2010).

Spalk atau fiksasi selang intra vena (IV) merupakan alat yang dirancang untuk melindungi area IV yang digunakan pada bayi dan anak untuk menghindari lepasnya jarum atau kateter (Wong et al., 2009). Menurut Dalal et al. (2009) pengguanan spalk atau bidai dapat mengurangi gerak atau immobilisasi sendi pada pemasangan infus. Berdasarkan penelitian ini penggunaan spalk masih efektif pada pasien anak.

Spalk atau bidai yang digunakan di RSUD Kab. Mamuju masih terbuat dari potongan karton yang dilapisi dengan kain kasa sehingga pada saat pemasangan infus sering menimbulkan rasa takut, cemas dan ketidaknyamanan pada anak karena jari-jari tangan ikut terfiksasi. Spalk Manakarra dirancang mengikuti struktur anatomi tangan anak sehingga nyaman untuk dipakai. Spalk ini juga dilapisi dengan kain yang lembut, bermotif boneka, berwarna cerah dan dilengkapi dengan boneka kecil yang dapat menyala. Hal ini dibuat sebagai distraksi pada saat pemasangan infus. Memanipulasi dengan cara distraksi pada prosedur yang mengakibatkan perlukaan tubuh dapat mengurangi ketakutan dan kecemasan pada anak (Nursalam, Susilaningrum, \& Utami, 2005).

\section{METODE PENELITIAN}

Penelitian ini merupakan penelitian quasi eksperiment dengan rancangan post test with control group design. Populasi adalah semua anak yang dirawat di RSUD Kabupaten Mamuju. Subjek penelitian diperoleh dengan purposive sampling yaitu anak yang dirawat di ruang perawatan anak Cempaka RSUD Kabupaten Mamuju yang memenuhi kriteria antara lain: anak yang terpasang infus, berusia 3-6 tahun, anak dalam kondisi sadar, dan orang tua bersedia menandatangani informed consent.

Variabel bebas dalam penelitian ini adalah Spalk Manakarra. Spalk "Manakarra" merupakan singkatan dari Spalk "Mainan Anak Kreativitas Perawat" yang dirancang sebagai alternatif spalk untuk menurunkan tingkat kecemasan anak pada saat pemasangan infus. Kata Manakarra diambil dari bahasa daerah Mamuju dan merupakan logo/lambang dari Kabupaten Mamuju. Kata ini diambil sebagai penciri daerah yang berarti pusaka yang sakti atau petunjuk.

Spalk Manakarra yang digunakan seperti gambar di bawah ini :
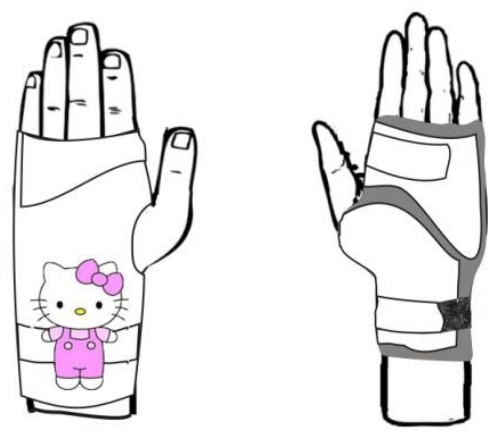

Gambar 1 Spalk Manakarra

Variabel terikat adalah tingkat kecemasan. Pengumpulan data dilakukan dengan mengisi lembar observasi tingkat kecemasan anak pra sekolah. Kuesioner yang digunakan mengacu pada kuesioner tingkat kecemasan Hamilton Rating Scala For Anxiety (HARS).

Analisis data dilakukan dengan analisis deskriptif dengan menampilkan distribusi dan persentase dari tiap variabel. Selanjutnya dilakukan analisis untuk menguji hipotesis 
tentang efektivitas pemasangan Spalk Manakarra terhadap penurunan tingkat kecemasan anak pra sekolah menggunakan independent sample $t$ test, dengan tingkat kepercayaan $95 \%(\alpha 0,05)$.

\section{HASIL PENELITIAN}

\section{Karakteristik responden}

Tabel 1. Distribusi rata-rata umur responden di Ruang Perawatan Anak Cempaka RSUD Kabupaten Mamuju

\begin{tabular}{lllll}
\hline Variabel & Kelompok & $\mathrm{n}$ & Mean \pm SD & $\begin{array}{l}\text { Min- } \\
\text { Maks }\end{array}$ \\
\hline Umur Ibu & Kontrol & 15 & $27,93 \pm 4,95$ & $23-38$ \\
& Intervensi & 15 & $27,00 \pm 3,98$ & $22-33$ \\
\hline Umur & Kontrol & 15 & $4,20 \pm 1,21$ & $3-6$ \\
Anak & Intervensi & 15 & $3,87 \pm 0,99$ & $3-6$
\end{tabular}

Tabel 1 menunjukkan bahwa rata-rata usia ibu pada kelompok kontrol adalah 27,93 tahun dengan usia minimun 23 tahun dan maksimum 38 tahun, sedangkan rata-rata usia ibu pada kelompok intervensi adalah 27 tahun dengan usia minimun 22 tahun dan maksimum 33 tahun. Rata-rata usia anak pada kelompok kontrol adalah 4,2 tahun, sedangkan rata-rata usia anak pada kelompok intervensi adalah 3,87 tahun.

Tabel 2. Distribusi frekuensi responden berdasarkan jenis kelamin di Ruang Perawatan Anak Cempaka RSUD Kabupaten Mamuju

\begin{tabular}{lcccc}
\hline \multirow{2}{*}{ Variabel } & \multicolumn{2}{c}{ Kontrol } & \multicolumn{2}{c}{ Intervensi } \\
\cline { 2 - 5 } & $\mathrm{n}$ & $\%$ & $\mathrm{n}$ & $\%$ \\
\hline Laki-laki & 8 & 53,3 & 11 & 73,3 \\
Perempuan & 7 & 46,7 & 4 & 26,7 \\
\hline
\end{tabular}

Tabel 2 menunjukkan bahwa jenis kelamin responden pada kelompok kontrol dan intervensi terbanyak adalah laki-laki yang berjumlah $8(53.3 \%)$ dan $11(73.3 \%)$

Tabel 3. Distriusi frekuensi tingkat kecemasan responden setelah pemasangan spalk di Ruang Perawatan Anak Cempaka RSUD Kabupaten Mamuju

\begin{tabular}{ccccc}
\hline \multirow{2}{*}{ Variabel } & \multicolumn{2}{c}{ Kontrol } & \multicolumn{2}{c}{ Intervensi } \\
\cline { 2 - 5 } & $\mathrm{n}$ & $\%$ & $\mathrm{n}$ & $\%$ \\
\hline Tidak Cemas & 0 & 0 & 3 & 20 \\
Cemas Ringan & 10 & 66,7 & 10 & 66,7 \\
Cemas Sedang & 5 & 33,3 & 2 & 13,3 \\
\hline
\end{tabular}

Tabel 3 menunjukkan tingkat kecemasan pada kelompok kontrol paling banyak dengan tingkat kecemasan ringan $10(66,7 \%)$ dan kecemasan sedang sebanyak $5 \quad(33,3 \%)$. Sedangkan pada kelompok intervensi ada penurunan tingkat kecemasan menjadi tidak cemas 3 (20\%) walaupun paling banyak dengan tingkat kecemasan ringan 10 (66,7\%).

\section{Analisis Bivariat}

Menganalisis tingkat kecemasan menggunakan "Spalk Manakara" pada pemasangan infus anak pra sekolah di RSUD Kabupaten Mamuju

Tabel 4. Rata-Rata \pm SD Tingkat Kecemasan Setelah Pemasangan Spalk Di Ruang Perawatan Anak Cempaka RSUD Kabupaten Mamuju

\begin{tabular}{ccccc}
\hline Variabel & Kelompok & $\mathrm{n}$ & Mean \pm SD & $p$ \\
\hline Tingkat & Kontrol & 15 & $18,7 \pm 4,32$ & \\
Kecemasan & Intervensi & 15 & $14,3 \pm 5,26$ & 0,026 \\
& & & &
\end{tabular}

Tabel 4. menunjukkan ada perbedaan yang bermakna tingkat kecemasan anak antara intervensi yang dipasang Spalk Manakarra dengan kelompok kontrol yang dipasang spalk rumah sakit dengan nilai $p=0,026$. 


\section{PEMBAHASAN}

\section{Umur}

Karakteristik umur anak pada kelompok kontrol adalah 4,2 tahun dengan standar deviasi 1,21 dan kelompok intervensi 3,87 tahun dengan standar deviasi 0,99. Temuan ini sejalan dengan usia rata-rata umur anak yang dirawat pada penelitian (Subandi, 2012) yaitu $(4,2 \pm 1,13$ vs $4,7 \pm 0,98)$ dan penelitian (Subardiah, 2009) dengan ratarata umur $4,77 \pm 0,83$. Melihat data tersebut rata-rata usia anak yang mengalami perawatan berkisar pada usia balita. Hal ini sesuai dengan pendapat Soetjiningsih (2005) bahwa usia yang paling rawan adalah usia balita karena pada masa ini anak mudah sakit dan mudah kekurangan gizi.

Usia pra sekolah juga merupakan tahap awal anak masuk dunia sekolah dan bermain, interaksi dengan teman sebaya memungkinkan anak terpapar dengan penyakit menular yang terjadi pada anak di sekolah. Hal ini dapat dilihat rata-rata anak yang dirawat di RSUD Kab. Mamuju disebabkan penyakit infeksi saluran pernapasan akut (ISPA).

\section{Jenis Kelamin}

Karakteristik jenis kelamin anak pada kelompok intervensi dan kontrol didominasi anak laki-laki $(53,3 \%$ vs $73,3 \%$ ). Hal ini sejalan dengan penelitian (Subandi, 2012) yang menunjukkan bahwa anak yang dirawat di rumah sakit laki-laki vs perempuan $(58,3 \%$ vs $54,5 \%)$ dan temuan yang sama oleh (Subardiah, 2009) dengan jenis kelamin laki-laki sebanyak $66,7 \%$.

Beberapa penelitian di atas menunjukkan bahwa anak laki-laki lebih banyak mengalami hospitalisai, Karakteristik lakilaki dan perempuan sering menjadi perbandingan tetapi belum diketahui penyebabnya mengapa jumlah responden laki-laki selalu lebih banyak dari perempuan (Soetjiningsih, 2005). Hal ini mungkin disebabkan karena anak laki-laki lebih senang bermain di luar rumah sehingga mudah terjangkit penyakit dibandingkan dengan anak perempuan.

\section{Tingkat Kecemasan}

Pada umumnya hospitalisasi akan menimbulkan kecemasan pada anak. Beberapa penelitian yang menunjukkan adanya hubungan antara kecemasan dengan hospitalisasi seperti penelitian yang dilakukan oleh Rini et al. (2013); Breving et.al. (2015); Pulungan et al. (2017). Tingkat kecemasan anak bervariasi mulai dari cemas ringan sampai cemas sedang. American Heart Association (AHA) tahun 2003, menyatakan anak-anak sangat rentan terhadap stres yang berhubungan dengan prosedur tindakan invasif. Pemasangan infus tentu saja akan menimbulkan nyeri, rasa sakit pada anak, dan juga akan menimbulkan trauma sehingga anak akan mengalami kecemasan dan stres.

Kecemasan juga disebut dengan ketakutan atau perasaan gugup. Beberapa kasus kecemasan (5-42\%), merupakan suatu perhatian terhadap proses fisiologis. Kecemasan ini dapat disebabkan oleh penyakit fisik atau keabnormalan, tidak oleh konflik emosional (Stuart dan Sunden, 2007), sehingga tindakan yang dilakukan dalam mengatasi masalah anak apapun bentuknya harus berlandaskan pada prinsip atraumatic care.

Hasil penelitian ini menunjukkan perbedaan yang bermakna tingkat kecemasan anatara kelompok intervensi dan kontrol. Hal ini menjelaskan bahwa Spalk Manakarra efektif menurunkan tingkat kecemasan anak pada saat pemasangan infus. Penelitian ini juga membuktikan bahwa spalk Manakarra dapat digunakan sebagai alat dalam melaksanakan asuhan atraumatic care. Hal ini juga sejalan dengan penelitian yang dilakukan oleh (Subandi, 2012) yang menyatakan adanya pengaruh pemasangan spalk bermotif terhadap tingkat kooperatif anak usia pra sekolah selama prosedur 
injeksi intra vena di rumah sakit Wilayah Cilacap.

Beberapa penelitian juga telah membuktikan bahwa penerapan atraumatic care memiliki pengaruh atau hubungan terhadap penurunan respon kecemasan pada anak yang mengalami hospitalisasi (Bolin, 2011 \& Breving et al., 2015). Gold (2006) juga menyatakan dalam penelitiannya bahwa menggunakan media virtual reality selama pemasangan infus memberikan ketenangan pada anak, mengurangi kecemasan serta meningkatkan sikap kooperatif pasien selama tindakan keperawatan. Penelitian lain oleh (Natalie, 2011) menunjukkan terapi bermain dengan menggunakan teknik bercerita berpengaruh terhadap tingkat kooperatif anak usia pra sekolah selama dirawat di rumah sakit.

Atraumatic care sebagai asuhan terapeutik memiliki beberapa tujuan seperti jangan melukai, mencegah dan mengurangi stres fisik dan psikologis. Distres psikologis meliputi kecemasan, ketakutan, kemarahan, kekecewaaan, kesedihan, malu, atau rasa bersalah. Distres fisik seperti kesulitan tidur dan immobilisasi sampai pengalaman stimulus sensori yang mengganggu seperti rasa sakit (nyeri), temperatur ekstrem, bunyi keras, cahaya yang dapat menyilaukan atau kegelapan dapat diminimalkan (Wong, 2009; Supartini, 2014).

Asuhan terapeutik tersebut mencakup pencegahan, diagnosis, atau penyembuhan kondisi akut atau kronis. Intervensi berkisar dari pendekatan psikologis berupa menyiapkan anak-anak untuk prosedur pemeriksaaan, sampai pada intervensi fisik seperti menyediakan ruangan untuk orang tua tinggal bersama anak dalam satu kamar (rooming in). (Wong et al., 2009).

Melihat banyaknya penelitian terkait dengan perawatan atraumatik, peneliti juga merekomendasikan agar rumah sakit menggunakan Spalk Manakarra untuk menurunkan tingkat kecemasan anak selama pemasangan infus dirumah sakit.

\section{SIMPULAN}

1. Tingkat kecemasan anak pra sekolah pada saat pemasangan infus di Ruang Perawatan Anak Cempaka RSUD Kab. Mamuju paling banyak dengan tingkat kecemasan ringan.

2. Spalk Manakarra efektif menurunkan tingkat kecemasan anak pra sekolah pada saat pemasangan infus.

\section{SARAN}

1. Spalk Manakarra dapat digunakan sebagai alternatif spalk yang dapat mengurangi kecemasan anak pada pemasangan infus di rumah sakit.

2. Spalk Manakarra dapat digunakan sebagai bahan inovasi yang dapat dikembangkan untuk meningkatkan kreativitas perawat.

\section{DAFTAR PUSTAKA}

Batalha, L. M. C., Costa, L. P. S., Almeida, D. M. G., Lourenco, P. A. A., Goncalves, A. M. F. M., Teixeire, A. C. G. (2010). Setting of peripheral venous catheter in children: comparative study. Esc Anna Nery (impr). 14(3): 511-518.

Bolin, N. (2011). Hubungan penerapan atraumatik care dalam pemasangan infus terhadap respon kecemasan pada anak yang mengalami hospitalisasi di Irna D Anak Rumah Sakit Dr. M. Djamil Padang tahun 2010. Skripsi. Padang: Universitas Andalas

Breving, R. M., Ismanto, A. Y., Onibala, F. (2015). Pengaruh penerapan atraumatic care terhadap respon kecemasan anak yang mengalami hospitalisasi di RSU Pancaran Kasih GMIM Manado dan RSUP Prof. DR. R.D. Kandou Manado. eJournal Keperawatan. 3(2): 1-9

Cahyaningrum, D. S. (2012). Pertumbuhan Perkembangan Anak dan Remaja. Jakarta: CV. Trans Info Media.

Dalal, S. S., Chawla, D., Singh, J., Agarwal, R. K., Deorari, A. K., \& Paul, V. K. (2009). 
Limb splinting for intravenous cannulae in neonates: a randomized controlled trial. Arch Dis Child Fetal Neonatal 94, 394396.

Festini, F., Occhipinti, V., De Martino, M.,Caprilli, S. (2009). Use of nonconventional nurse's attire in a pediatric hospital: a quasi-experimental study. Jornal of Clinical Nursing.18(7): 10181026.

Fletcher, K. E. (2003). Child Psychopathology. New York: The Guilford Press.

Gold, J. I., Kim, S. H., Kant, A. J., Joseph, M. H., \& Rizzo, A. (2006). Effectiveness of virtual reality for pediatric pain distraction during IV placement. Cyber Psychology \& Behavior. 9(2): 207-213.

Kementerian Pemberdayaan Perempuan dan Perlindungan Anak. (2015). Profil Anak Indonesia 2015. Jakarta: Kementerian Pemberdayaan Perempuan dan Perlindungan Anak serta Badan Pusat Statistik.

Muscari, M. E. (2005). Keperawatan Pediatrik. Jakarta: EGC.

Natalie, E. (2011). Pengaruh Terapi Bermain dengan Teknik Bercerita terhadap Tindakan Kooperatif Anak Usia Pra Sekolah (3-6 Tahun) Selama Hospitalisasi di Rumah Sakit Dirgahayu Samarinda. Surabaya: Fakultas Keperawatan Universitas Airlangga.

Nursalam, N., Susilaningrum, R., \& Utami, S. (2005). Asuhan Keperawatan Bayi dan Anak (untuk Perawat dan Bidan). Jakarta: Salemba Medika.

Soetjiningsih, S. (2005). Tumbuh Kembang Anak. Jakarta: EGC.

Stuart \& Sundeen. (2007). Buku Saku Keperawatan Jiwa. Edisi 4. Jakarta: EGC

Subandi, A. (2012). Pengaruh Pemasangan Spalk Bermotif terhadap Tingkat Kooperatif Anak Usia Pra Sekolah Selama Prosedur Injeksi Intra Vena di Rumah Sakit Wilayah Cilacap. Depok: FIK-UI.
Subardiah, P. I. (2009). Pengaruh Permainan Terapeutik terhadap Kecemasan, Kehilangan Kontrol, dan Ketakutan Anak Pra Sekolah Selam Dirawat di RSUD Dr.H. Abdul Moeloek Provinsi Lampung. Depok: FIK-UI.

Supartini, Y. (2004). Buku Ajar Konsep Dasar Keperawatan Anak. Jakarta: EGC.

Pulungan, Z. S. A., Purnomo, E., Purwanti, A. (2017). Hospitalisasi mempengaruhi tingkat kecemasan anak toddler. Jurnal Kesehatan Manarang. 3(2): 58-63

Rini, D. M., Sari, R., Rahmawati, I. (2013). Hubungan penerapan atraumatic care dengan kecemasan anak pra sekolah saat proses hospitalisasi di RSU dr. H. Koesnadi Kabupaten Bondowoso. Artikel Ilmiah Hasil Penelitian Mahasiswa. 1-8

Wong, D. L., Hockenberry, M., Eaton, Wilson, D., Winkelstein, M. L., \& Schwartz, P. (2009). Buku Ajar Keperawatan Pediatrik. Jakarta: EGC. 